\title{
Recombinant Human Soluble Thrombomodulin is Effective for Severe Childhood EBV-HLH
}

Keywords: Epstein-Barr Virus-Associated Hemophagocytic Lymphohistiocytosis (EBV-HLH); Recombinant Human Soluble Thrombomodulin (rTM); Disseminated Intravascular Coagulation (DIC); Coagulopathy

\begin{abstract}
Hemophagocytic lymphohistiocytosis (HLH) is a fatal disease presenting with $T$ cell-induced dysregulated cytokine production, systemic inflammation, and frequently intractable coagulopathy. We have administered recombinant human soluble recombinant thrombomodulin (rTM) for four cases of severe childhood Epstein-Barr virus-associated HLH (EBV-HLH) in combination with anti-inflammatory therapy and had good clinical outcomes. To evaluate its efficacy, we retrospectively compared to the former six cases without rTM administration. The patients were admitted between May 2003 and July 2014. The median age at diagnosis was 8.2 years (range, 1.6-16 years). All patients except for two cases without rTM who received only steroid, were treated with steroid, cyclosporine A (CSP) and/or etoposide based on HLH-94 or HLH-2004. All patients receiving rTM were induced in remission. However, two patients without rTM administration died of disease progression. The values of FDP, D-dimer, serum ferritin, and bilirubin improved better in patients with rTM. In some cases without rTM, serum bilirubin increased even though D-dimer, FDP, and ferritin were decreased. Although further clinical experience is required, rTM may be effective as an adjuvant therapy for resolution of severe EBV-HLH.
\end{abstract}

\section{Introduction}

EB virus associated hemophagocytic syndrome (EBV-HLH) is characterized by clinical manifestations such as fever, cytopenia, and hepatosplenomegaly. It is assumed that main pathology of EBV-HLH is hypercytokinemia induced by the abnormal activation of $\mathrm{T}$ cells and the macrophages based on some kind of abnormality in the EBVspecific cell mediated immunity, and EBV-HLH usually presents with coagulation disorder and disseminated intravascular coagulation (DIC). It is said that the poor therapeutic response case often follows fatal course [1].

Thrombomodulin is a glycoprotein present on vascular endothelial cells and is responsible for regulation of the coagulation pathway via thrombin. Recombinant human soluble thrombomodulin (rTM), a gene recombinant product of thrombomodulin, has been developed as a disseminated intravascular coagulation (DIC) therapeutic agent. A Phase III trial in 2007 elucidated the non-inferiority of rTM for use in tumor-related and infection-related DIC by comparison with heparin sodium [2]. Thereafter, the efficacy of rTM has been supported by a numerous reports, particularly in treatment of sepsisinduced DIC [3-6]. It was also shown in case reports that rTM was effective in microangiopathy of bone marrow transplantation $[7,8]$ and capillary leak of engraftment syndrome [9].

In addition to its anticoagulant effect, an anti-inflammatory
Journal of

Hematology \& Thrombosis

Chika Kobayashi ${ }^{1,2}$, Masayuki Nagasawa ${ }^{13^{*}}$, Noriko Mitsuiki ${ }^{1,2}$, Akifumi Endo', Yuki Aoki', Toshiaki Ono', Kohsuke Imai', Masatoshi Takagi', Michiko Kajiwara ${ }^{1}$ and Tomohiro Morio ${ }^{1}$

${ }^{\prime}$ Department of Pediatrics and Developmental Biology, Tokyo Medical and Dental University, 5-45 Yushima 1-chome, Bunkyo-ku, Tokyo 113-8519, Japan

${ }^{2}$ Department of Hematology Oncology and Immunology, Tokyo Bay Urayasu/Ichikawa Medical Center, 3-4-32, Todaijima, Urayasu-city, Chiba 279-0001, Japan

${ }^{3}$ Department of Pediatrics, Musashino Red Cross Hospital 1-26-1, Kyonan-cho, Musashino-city, Tokyo 180-8610, Japan

\section{*Address for Correspondence:}

Masayuki Nagasawa, M.D., Ph.D., Department of Pediatrics, Musashino Red Cross Hospital, 1-26-1, Kyonan-cho, Musashino-city, Tokyo 180-8610, Japan, Tel: +81-422-32-3111; Fax: +81-422-323525; E-mail: mnagasawa.ped@tmd.ac.jp

\section{Submission: 22 April, 2016}

Accepted: 29 April, 2016

Published: 05 May, 2016

Copyright: $\odot 2016$ Kobayashi C, et al. This is an open access article distributed under the Creative Commons Attribution License, which permits unrestricted use, distribution, and reproduction in any medium, provided the original work is properly cited.

Reviewed \& Approved by: Dr. Raul H. Morales-Borges, American Red Cross in San Juan, Practices, Ashford Institute of Hematology \& Oncology, USA

effect of rTM has been anticipated. It activates S1P1 (sphingosine 1-phosphate receptor 1) and subsequently PAR-1 (protease-activated receptor-1) [10], having a substantial effect on inflammation due to degradation of alarmins [including histones, nucleosomes, and high mobility group box 1 (HMGB1)] mediated by a lectin-like domain [11-13]. We have treated four cases of severe childhood EpsteinBarr virus-associated HLH (EBV-HLH) in combination with antiinflammatory therapy and had good clinical responses.

\section{Patient Characteristics and Case Reports}

The clinical characteristics of the patients are summarized in Table 1. The patients were diagnosed with EBV-HLH at our institution (nine patients from Tokyo Medical and Dental University and one from Tokyo Bay Urayasu/Ichikawa Medical Center) between May 2003 and July 2014. HLH was clinically diagnosed according to the diagnostic criteria used in the HLH-2004 trial [14]. The median age at diagnosis was 8.2 years (range, 1.6-16 years). At least four patients were suspected to have underlying diseases. One patient (case 1) was diagnosed with X-linked lymphoproliferative disease 1 (XLP1), and some of the other patients (cases 2, 3, and 7) also appeared to have some undetermined immunodeficiency.

Dexamethasone (DEX), CSP, and etoposide therapy based on HLH-2004 was administered in case 1, 2, 3, 4, 6, and 7. Two patients (cases 5 and 9) were treated based on HLH-94. The case 8 and 10 were cured with steroids alone. Prednisolone (PSL) was used instead of DEX in cases 7 and 10. Dalteparin (low-molecular-weight heparin) was administered in cases $1,3,4,8$, and 10 and heparin in cases 2, 3, 5, 
Citation: Kobayashi, C Nagasawa M, Mitsuiki N, Endo A, Aoki Y. Recombinant Human Soluble Thrombomodulin is Effective for Severe Childhood EBV-HLH. J Hematol Thromb 2016;2(1): 4.

and 7 as supportive therapies for DIC. In addition, blood transfusion [Red cell concentrates (RCC), platelet concentrate (PC), fresh frozen plasma (FFP)], albumin, and antithrombin III were administered as needed. All patients presented coagulation disorders compatible with DIC.

We administered rTM to four patients (case 1-4) admitted to the hospital after 2011. The dose of rTM was $380 \mathrm{U} / \mathrm{kg}$; the administration period was 4, 6, and 7 days (Case 2-4); and rTM was administered for more than 30 days in one case (case 1 ).

In case 2, a 2-year-old girl had received PSL (2 mg/kg/day) for systemic inflammatory response syndrome (SIRS) before the diagnosis of EBV-HLH. Despite treatment, coagulopathy accompanying purpura and mucosal bleeding developed and rTM was administered. Although remission could not be achieved, she was able for a week until the start of intensive treatment with DEX, CSP, and etoposide, when she was diagnosed as EBV-HLH because of a detection of hemophagocytosis in the bone marrow and high copy number of EBV genome in the peripheral blood. Although natural killer (NK) cell cytolytic activity has been low, she has been in remission for more than two years without medications. Perforin, Munc13-4, Syntaxin11 and SH2D1A (SH2 domain-containing protein 1A) genes were normal.

Table 1: Patient characteristics: The clinical characteristics and treatment outcomes of EBV-HLH patients treated with or without recombinant thrombomodulin (rTM)

\begin{tabular}{|c|c|c|c|c|c|c|c|c|c|c|}
\hline Case & $\begin{array}{c}\text { Age (years) } \\
\text { gender }\end{array}$ & $\begin{array}{l}\text { Immune } \\
\text { deficiency }\end{array}$ & Clinical symptoms & $\begin{array}{c}\text { EBV copy } \\
\text { number } \\
\text { copy/mg DNA }\end{array}$ & Therapy & rTM duration & $\begin{array}{c}\text { Supportive } \\
\text { care }\end{array}$ & $\begin{array}{c}\text { Response } \\
\text { to treatment }\end{array}$ & Exacerbation & Outcome \\
\hline 1 & $2 \mathrm{M}$ & $\begin{array}{l}\mathrm{XLP}-1 \\
(S A P)\end{array}$ & $\begin{array}{l}\text { Fever, rush, } \\
\text { pancytopenia, } \\
\text { lymphadenopathy, } \\
\text { fluid retention }\end{array}$ & $9 \times 10^{4}$ & $\begin{array}{l}\text { DEX CSP } \\
\text { etoposide }\end{array}$ & $>30$ days & $\begin{array}{l}\text { Dalteparin, } \\
\text { FFP } \\
\text { PC, Alb, } \\
\text { ATIII }\end{array}$ & $>20$ days & 0 & Alive \\
\hline 2 & $2 \mathrm{~F}$ & + & $\begin{array}{l}\text { Fever, rush, } \\
\text { pancytopenia, } \\
\text { lymphadenopathy, } \\
\text { hepatosplenomegaly, } \\
\text { fluid retention }\end{array}$ & $1.1 \times 10^{6}$ & $\begin{array}{l}\text { DEX CSP } \\
\text { etoposide }\end{array}$ & 6 days & $\begin{array}{c}\text { FFP, RCC, } \\
\text { Vit K }\end{array}$ & 17 days & 0 & Alive \\
\hline 3 & $6 \mathrm{M}$ & + & $\begin{array}{l}\text { Fever, pancytopenia, } \\
\text { hepatosplenomegaly, } \\
\text { fluid retention, emesis, } \\
\text { diarrhea }\end{array}$ & $9 \times 10^{4}$ & $\begin{array}{l}\text { DEX CSP } \\
\text { etoposide }\end{array}$ & 7 days & $\begin{array}{l}\text { Dalteparin, } \\
\text { FFP, } \\
\text { PC, Alb, } \\
\text { ATIII }\end{array}$ & 14 days & 1 & BMT Alive \\
\hline 4 & $10 \mathrm{~F}$ & - & $\begin{array}{l}\text { Fever, rush, } \\
\text { pancytopenia, } \\
\text { lymphadenopathy, } \\
\text { hepatosplenomegaly }\end{array}$ & $3 \times 10^{5}$ & DEX CSP & 4 days & $\begin{array}{l}\text { Dalteparin, } \\
\text { PC, ATIII }\end{array}$ & 4 days & 0 & Alive \\
\hline 5 & $9 \mathrm{M}$ & - & $\begin{array}{l}\text { Fever, pancytopenia, } \\
\text { lymphadenopathy, } \\
\text { hepatosplenomegaly, } \\
\text { fluid retention, } \\
\text { abdominal pain }\end{array}$ & $3 \times 10^{5}$ & $\begin{array}{l}\text { DEX CSP } \\
\text { etoposide }\end{array}$ & - & $\begin{array}{c}\text { heparin, PC, } \\
\text { FFP, } \\
\text { ATIII }\end{array}$ & 13 days & 3 & Dead \\
\hline 6 & $6 \mathrm{M}$ & - & $\begin{array}{l}\text { Fever, pancytopenia, } \\
\text { lymphadenopathy, } \\
\text { hepatosplenomegaly, } \\
\text { fluid retention, } \\
\text { abdominal pain, arthritic } \\
\text { pain, lung infiltration }\end{array}$ & $2.3 \times 10^{6}$ & $\begin{array}{l}\text { DEX CSP } \\
\text { etoposide }\end{array}$ & - & PC & 5 days & 0 & Alive \\
\hline 7 & $3 \mathrm{~F}$ & + & $\begin{array}{l}\text { Fever, pancytopenia, } \\
\text { lymphadenopathy, } \\
\text { hepatosplenomegaly, } \\
\text { fluid retention, diarrhea }\end{array}$ & $3.9 \times 10^{5}$ & $\begin{array}{l}\text { PSL CSP } \\
\text { etoposide }\end{array}$ & - & $\begin{array}{l}\text { heparin, PC, } \\
\text { FFP, RCC, } \\
\text { ATIII, FUT, }\end{array}$ & $>20$ days & 0 & Dead \\
\hline 9 & $16 \mathrm{~F}$ & - & $\begin{array}{l}\text { Fever, pancytopenia, } \\
\text { lymphadenopathy, } \\
\text { hepatosplenomegaly, } \\
\text { delirium, nausea, } \\
\text { aphose }\end{array}$ & NA & $\begin{array}{l}\text { DEX CSP } \\
\text { etoposide }\end{array}$ & - & - & 12 days & 2 & Alive \\
\hline 10 & $10 \mathrm{~F}$ & - & $\begin{array}{l}\text { Fever, pancytopenia, } \\
\text { lymphadenopathy, } \\
\text { hepatosplenomegaly, } \\
\text { delirium, muscle pain, } \\
\text { headache }\end{array}$ & NA & PSL & - & - & 5 days & 0 & Alive \\
\hline
\end{tabular}

Response to treatment means a period of time (days) until D-dimer became normal after treatment.

DEX: Dexamethasone; CSP: Cyclosporine A; Alb: Albumin; FFP: Fresh Frozen Plasma; PC: Platelet Concentrate; RCC: Red Cell Concentrates;

ATIII: Antithrombin III; FOY: gabexate mesilate; FUT: Nafamostat Mesilate; BMT: Bone Marrow Transplantation; M: Male; F: Female; NA: Not Available Exacerbation means the number of re-increase of D-dimer once it was normalized. 


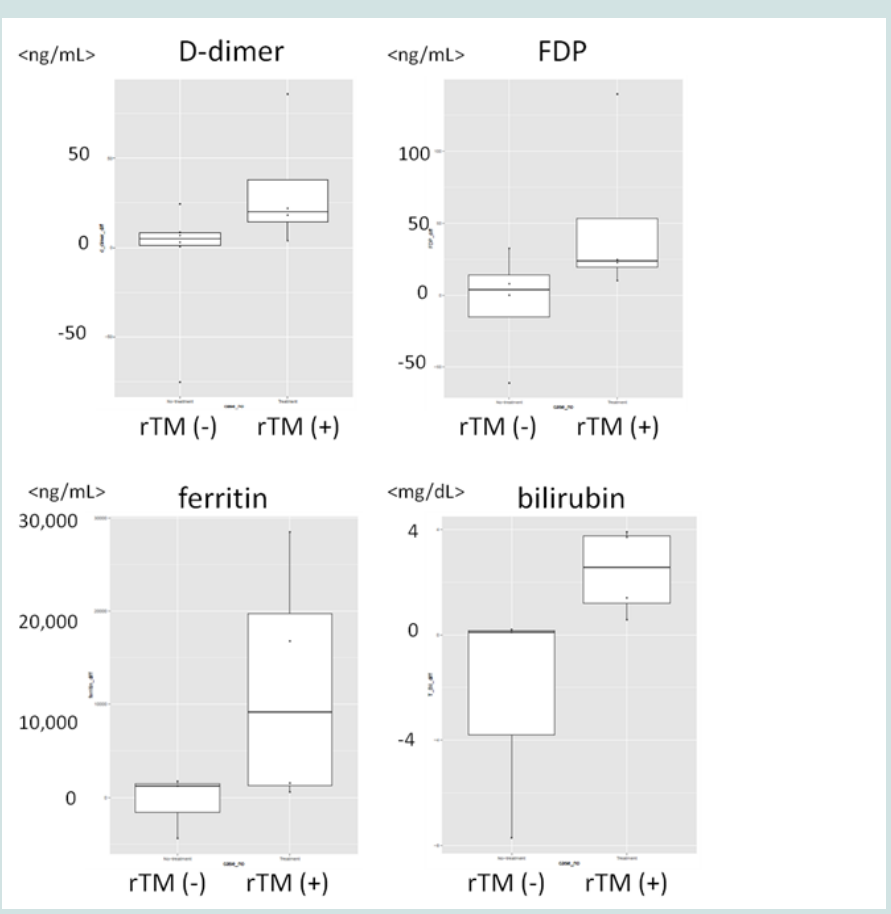

Figure 1: Thrombomodulin improved clinical parameters more efficiently.

Clinical parameters of D-dimer, FDP, ferritin and total bilirubin were compared between patients treated with $r T M(n=4)$ and without $r T M(n=6)$.

The differences of each parameter before and two weeks after treatment were plotted. Positive number indicates improvement and negative number indicates deterioration.

Not statistically significant, all four parameters improved better in patients with rTM.

Without rTM, serum bilirubin slighly increased even though D-dimer, FDP, and ferritin were decreased. Box plot presents maximum, $75 \%$, mean, $25 \%$, and minimum value respectively..

In case 3, a 6-year-old boy was referred to our hospital because of prolonged fever, hepatosplenomegaly, emesis, and diarrhea. He had already received rTM one day prior to admission. Laboratory evaluation revealed pancytopenia; lactate dehydrogenase (LDH) was $1391 \mathrm{U} / \mathrm{L}$, ferritin was $21,593 \mathrm{ng} / \mathrm{dL}$, the level of soluble interleukin 2 receptor (s-IL2 R) was $23,800 \mathrm{U} / \mathrm{mL}$, and conjugated-bilirubin was elevated to $3.0 \mathrm{mg} / \mathrm{dL}$. A bone marrow aspiration showed hemophagocytosis. He suddenly developed respiratory failure with pleural effusion on the next day of admission. The HLH-2004 protocol, including DEX $\left(10 \mathrm{mg} / \mathrm{m}^{2}\right), \operatorname{CSP}(3 \mathrm{mg} / \mathrm{kg})$, and etoposide was started immediately with methyl prednisolone (mPSL) pulse therapy as indicated. Subsequently, clinical symptoms and laboratory signs gradually improved. Unfortunately, a relapse occurred 2 months after remission, and he received bone marrow transplantation from an HLA-compatible sibling and was stable and in remission thereafter. Genetic abnormalities of the SH2D1A, BIRC4 (Baculoviral IAP repeat-containing protein 4), and IL-2-inducible T-cell kinase (ITK) genes as well as Perforin, Munc13-4, and Syntaxin11 genes were not detected.

On the other hand, the courses of the patients without rTM administration with regrettable outcomes are described below. In case 5, a 9-year-old boy had disease reactivation 3 months after initiation of therapy during administration of DEX, CSP, and etoposide. He received mPSL pulse therapy and chemotherapy of CHOP-regimen (vincristine, cyclophosphamide, adriamycin), and eventually high-dose cytarabine. However, he developed multi-organ failure and died 5 months later. No definitive immunodeficiency was determined.
Case 7 was a 3 -year-old girl with chronic diarrhea. She had a history of eight bacterial infection episodes until the age of 3 years and specific antibody production failure. Although some immunodeficiency had been suspected, a definite diagnosis had not been established. In the course of recurrent infection, she presented with fever, lymphadenopathy, and hepatosplenomegaly. In addition, the presence of EBV-infected B cells in the peripheral blood was confirmed. PSL, CSP and etoposide were initiated according to the diagnosis of fulminant infectious mononucleosis or EBV-HLH. However, exacerbation of DIC led to a fatal course with pulmonary hemorrhage, gastrointestinal bleeding, and abdominal hemorrhage. Later, the proliferation of EBV positive NK cells and $\gamma \delta \mathrm{T}$ cells in the biopsied lymph nodes was confirmed.

To evaluate the efficacy of rTM, the differences of each value of D-dimer, FDP, ferritin, and bilirubin between before and two weeks after treatment were compared. As shown in Figure 1, D-dimer, FDP, and ferritin were improved more efficiently in the cases with rTM administration, although not statistically significant because of small case number. Interestingly, elevated bilirubin was improved in all of the cases with rTM administration but elevated bilirubin was unchanged or increased even after treatment in cases without rTM administration (Figure 1).

\section{Discussion}

Since 2008, rTM has been available clinically for the treatment of DIC in Japan.

Here, we report 10 children with severe EBV-HLH since 2003, 
and the latter four cases were treated with rTM as an adjuvant therapy. All of four patients receiving rTM survived. Meanwhile, two of six patients who did not receive rTM failed to achieve remission and died, although both groups included patients with immunodeficiency and very severe conditions. Two cases in the $\operatorname{rTM}(-)$ group were dead of disease progression. It has been reported that serum ferritin values are closely related to disease activity and severity [1]. Mean serum ferritin values were even higher in the $\operatorname{rTM}(+)$ group than in the rTM(-) group $(13,011 \mathrm{ng} / \mathrm{mL}$ and $1,242 \mathrm{ng} / \mathrm{mL}$, respectively). Two cases (case 8 and 10) in rTM(-) group were treated with only steroid and induced in remission. In this regard, it appears that the $\operatorname{rTM}(+)$ group included more severe cases than in the $\mathrm{rTM}(-)$ group.

Serum ferritin and bilirubin improved more significantly in $\mathrm{rTM}(+)$ group compared with FDP and $\mathrm{D}$-dimer values. It is interesting that bilirubin values improved in the $\operatorname{rTM}(+)$ group, while slowly deteriorating in the $\mathrm{rTM}(-)$ group, with FDP and D-dimer values improving in both groups. In case 1 and 3, they were clinically complicated with hepatic veno-occlusive disease (hVOD), which improved dramatically after rTM treatment. Several cases have been reported that showed the remarkable effectiveness of rTM against hepatic VOD in patient with allogeneic stem cell transplantation (SCT) $[15,16]$. Yabe et al. have reported as a multi-center retrospective observation in Japan that rTM was remarkably effective in 19 out of 21 pediatric patients with allogeneic SCT, who were complicated with hepatic VOD [17]. It is difficult to conclude that the effect of rTM was not only based on the improved coagulopathy but also on the antiinflammatory activity of rTM from our limited experiences. However, recent research indicates that coagulation and inflammation are closely related with each other, and regulation of coagulopathy may lead to reduced inflammation [18]. Thus, it appears reasonable that the better clinical response in the $\operatorname{rTM}(+)$ group was partly attributable to the direct pharmacological effects of rTM. It seems that rTM may be useful to prevent progression of organ dysfunction, especially hepatic dysfunction in severe case of EBV-HLH in combination with immunosuppressive treatment, although monotherapy with rTM is not sufficient to control a disease activity as in the case 2 .

We conclude that rTM should be used in the early phase of the disease in case of severe EBV-HLH with severe coagulopathy as an adjuvant therapy in combination with anti-inflammatory standard therapy [14]. Administration of rTM was safely performed and adverse effects such as bleeding were not observed in our series, even in the presence of a therapeutic dose of heparin. Further clinical experience is required to confirm our suggestion.

\section{References}

1. Imashuku S (2002) Clinical features and treatment strategies of Epstein-Barr virus-associated hemophagocytic lymphohistiocytosis. Crit Rev Oncol Hematol 44: $259-272$.

2. Saito H, Maruyama I, Shimazaki S, Yamamoto Y, Aikawa N, et al. (2007) Efficacy and safety of recombinant human soluble thrombomodulin (ART-123) in disseminated intravascular coagulation: results of a phase III, randomized, double-blind clinical trial. J Thromb Haemost 5: 31-41.

3. Kawano N, Tasaki A, Kuriyama T, Tahara Y, Yoshida S, et al. (2014) Effects of recombinant human soluble thrombomodulin treatment for disseminated intravascular coagulation at a single institution--an analysis of 62 cases caused by infectious diseases and 30 cases caused by hematological diseases. Intern Med 53: 205-213.
4. Vincent JL, Ramesh MK, Ernest D, Larosa SP, Pachl J, et al. (2013) A randomized, double-blind, placebo-controlled, Phase $2 b$ study to evaluate the safety and efficacy of recombinant human soluble thrombomodulin, ART-123, in patients with sepsis and suspected disseminated intravascular coagulation. Crit Care Med 41: 2069-2079.

5. Kato T, Sakai T, Kato M, Hagihara M, Hasegawa T, et al. (2013) Recombinant human soluble thrombomodulin administration improves sepsis-induced disseminated intravascular coagulation and mortality: a retrospective cohort study. Thromb J 11: 3 .

6. Iba T, Yamada A, Hashiguchi N, Nagaoka I (2014) New therapeutic options for patients with sepsis and disseminated intravascular coagulation. Pol Arch Med Wewn 124: 321-328

7. Sakai M, Ikezoe T, Bandobashi K, Togitani K, Yokoyama A (2010) Successful treatment of transplantation-associated thrombotic microangiopathy with recombinant human soluble thrombomodulin. Bone Marrow Transplant 45: 803-805.

8. Nagasawa M, Ohkawa T, Endo A, Mitsuiki N, Ono T, et al. (2013) Early coagulation disorder after allogeneic stem cell transplantation is a strong prognostic factor for transplantation-related mortality, and intervention with recombinant human thrombomodulin improves the outcome: a single-center experience. Int J Hematol 98: 533-542.

9. Ikezoe T, Takeuchi A, Taniguchi A, Togitani K, Yokoyama A (2011) Recombinant human soluble thrombomodulin counteracts capillary leakage associated with engraftment syndrome. Bone Marrow Transplant 46: 616-618.

10. Toltl LJ, Beaudin S, Liaw PC, Canadian Critical Care Translational Biology Group (2008) Activated protein C up-regulates IL-10 and inhibits tissue factor in blood monocytes. J Immunol 181: 2165-2173.

11. Kambas K, Mitroulis I, Apostolidou E, Girod A, Chrysanthopoulou A, et al (2012) Autophagy mediates the delivery of thrombogenic tissue factor to neutrophil extracellular traps in human sepsis. PLoS One 7: e45427.

12. Li YH, Kuo CH, Shi GY, Wu HL (2012) The role of thrombomodulin lectin-like domain in inflammation. J Biomed Sci 19: 34

13. Nagato M, Okamoto K, Abe Y, Higure A, Yamaguchi K (2009) Recombinan human soluble thrombomodulin decreases the plasma high-mobility group box-1 protein levels, whereas improving the acute liver injury and survival rates in experimental endotoxemia. Crit Care Med 37: 2181-2186.

14. Henter Jl, Horne A, Aricó M, Egeler RM, Filipovich AH, et al. (2007) HLH2004: Diagnostic and therapeutic guidelines for hemophagocytic lymphohistiocytosis. Pediatr Blood Cancer 48: 124-131.

15. Nakamura D, Yoshimitsu M, Kawada H, Inoue H, Kuroki T, et al. (2012) Recombinant human soluble thrombomodulin for the treatment of hepatic sinusoidal obstructive syndrome post allogeneic hematopoietic SCT. Bone Marrow Transplant 47: 463-464

16. Ohwada C, Takeuchi M, Kawaguchi T, Tsukamoto S, Sakai S, et al. (2011) Successful treatment with recombinant soluble thrombomodulin of two cases of sinusoidal obstructive syndrome/hepatic veno-occlusive disease after bone marrow transplantation. Am J Hematol 86: 886-888.

17. Yabe H, Nagasawa M, Yagasaki H (2012) Recombinant human thrombomodulin is effective in the treatment of early complications after hematopoietic stem cell transplantation in children and adolescents, Stem Cell Transplantation Committee of Japanese Pediatric Leukemia/Lymphoma Study Group (JPLSG), I-BFM Annual Meeting, Isehara, Japan.

18. Wu Y (2015) Contact pathway of coagulation and inflammation. Thromb J 13: 17

\section{Acknowledgements}

This work was partly supported by Grant-in-Aid for Scientific Research Grant Number 16659273, 20591246, 24591541 to M.N. 